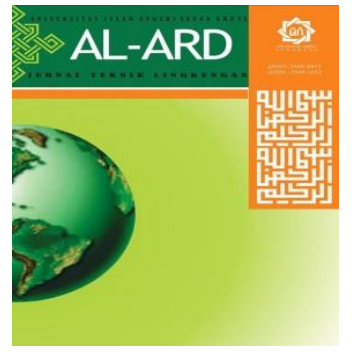

AL-ARD: JURNAL TEKNIK LINGKUNGAN

Vol.3 No.2 - Maret 2018 (70-77)

AL-ARD

JURNAL

TEKNIK LINGKUNGAN

www.al-ard.uinsby.ac.id

\title{
ANALISIS KEBISINGAN PADA INSTITUSI PENDIDIKAN DI FRONTAGE ROAD SISI TIMUR JALAN A.YANI SURABAYA
}

\author{
Widya Nilandita', Dyah Ratri Nurmaningsih ${ }^{2}$, Shinfi Wazna Auvaria ${ }^{3}$ \\ ${ }^{1}$ UIN Sunan Ampel, Surabaya, Indonesia \\ Widya.nilandita@uinsby.ac.id \\ 2UIN Sunan Ampel, Surabaya,Indonesia \\ dyahratrin@gmail.com \\ ${ }^{3}$ UIN Sunan Ampel, Surabaya, Indonesia \\ shinfiwazna@uinsby.ac.id
}

\begin{abstract}
Noise can occur anywhere, including at educational institutions. Noise research at educational institutions began to be studied a lot because of the negative impact on the teaching and learning process and disrupt the performance of teachers and students. Some studies show that schools or universities located on the edge of the road, show noise levels that exceed quality standards. This research was conducted at educational institutions located along the east Frontage Road Jl A.Yani Road, Surabaya, by measuring noise levels at 3 locations, in daylighting measurements with 4 measurement times (L1-L4). Data collection and processing was carried out by referring to the quality standard of KEPMENLH No. 48 of 1996. Data was measured using a sound level meter for 10 minutes for each measurement, with a reading every 5 seconds to obtain 120 data. Data processing results are compared with the standard noise level. The noise value at SD Margorejo I / 403 is $82.2 \mathrm{~dB}$, UIN Sunan Ampel Surabaya is $79.76 \mathrm{~dB}$, and SMK 3 Surabaya is $80.06 \mathrm{~dB}$. The noise level value has exceeded the established quality standard, which has maximum of $55 \mathrm{~dB}$ for the educational intitutions area. The source of noise comes from the activities of motorized vehicles in and around educational institution that is quite crowded. Another cause of the high noise value is the train activities along the east frontage road Jl A.yani Surabaya, as well as the distance of the noise source with research location that relatively close.
\end{abstract}

Keywords: noise, educational institution, sound level meter

\begin{abstract}
Abstrak
Kebisingan atau polusi suara dapat di terjadi di mana saja, termasuk pada Institusi pendidikan. Penelitian mengenai kebisingan di institusi pendidikan mulai banyak dikaji karena dampak negatif terhadap proses belajar mengajar dan mengganggu kinerja pengajara dan siswa. Beberapa penelitian menunjukkan sekolah atau universitas yang berada di tepi jalan raya menunjukkan tingkat kebisingan yang melampaui baku mutu. Penelitian ini dilakukan di institusi pendidikan yang berada di sepanjang Frontage Road Timur Jalan A.Yani Surabaya, dengan pengukuran tingkat kebisingan di 3 lokasi dan waktu pengukuran siang hari dengan 4 waktu pengukuran (L1-L4). Pengambilan dan pengolahan data dilakukan dengan mengacu pada baku mutu dari KEPMENLH No 48 tahun 1996. Data diukur menggunakan sound level meter selama 10 menit untuk setiap pengukuran, dengan pembacaan setiap 5 detik sehingga diperoleh 120 data. Hasil pengolahan data dibandingkan dengan baku mutu tingkat kebisingan. Besar nilai kebisingan pada SDN Margorejo I/403 sebesar 82,2 dB, Kampus UIN Sunan Ampel Surabaya 79,76 dB, dan SMKN 3 Surabaya 80,06 dB. Nilai tingkat kebisingan tersebut telah melampaui baku mutu yang di tetapkan, yaitu maksimal $55 \mathrm{~dB}$ untuk kawasan pendidikan. Sumber kebisingan tersebut berasal dari aktivitas kendaraan bermotor di dalam dan sekitar institusi pendidikan yang cukup padat. Penyebab lain tingginya nilai kebisingan adalah dari aktivitas kereta api yang berada di sepanjang frontage road Timur Jl A.yani Surabaya, serta jarak sumber kebisingan dengan lokasi penelitian yang relatif dekat.
\end{abstract}

Kata Kunci: kebisingan, institusi pendidikan, sound level meter 


\section{PENDAHULUAN}

Frontage road sisi timur jalan A.Yani Surabaya adalah jalan yang berpotensi mengalami peningkatan volume kendaraan yang tinggi. Frontage road timur berada di sebelah jalan arteri A.Yani Surabaya yang menghubungkan antara Surabaya dengan kota-kota lainnya. Beragam aktivitas berlangsung disepanjang frontage road Surabaya antara lain aktivitas perdagangan, aktivitas perkatoran, rumah sakit dan aktivitas pendidikan.

Terdapat beberapa aktivitas institusi pendidikan di frontage road timur antara lain universitas dan sekolah. Salah satu alasan mengapa di bangun institusi pendidikan di sepanjang jalan frontage road timur karena lokasi ini sangat strategis, mudah diakses oleh semua orang. Namun, terdapat dampak negatif dari lokasi strategis tersebut salah satu dampak negatif tersebut adalah terpapar kebisingan dari kendaraan yang melewati jalan.

Kendaraan adalah salah satu sumber kebisingan. Sumber bising dari kendaraan berasal dari suara mesin yang keluar dari knalpot dan klakson pada saat kendaraan beroperasi. Semakin banyak volume kendaraan semakin bertambah tingkat kebisingannya. Suara pada level tertentu yang masih bisa ditoleransi oleh masyarakat tidak akan menimbulkan gangguan kenyamanan, berbeda dengan suara pada level tinggi seperti suara dari kendaraan akan menimbulkan suatu polusi suara yang disebut kebisingan (Djalante,2010). Polusi suara atau kebisingan, menjadi salah satu permasalahan lingkungan yang perlu mendapat perhatian,selain polusi udara dan air.

Kebisingan umumnya didefinisikan sebagai suara yang tidak diinginkan dan mengganggu yang lebih tinggi dari tingkat normal suara yang nyaman untuk telinga manusia dan memiliki efek negatif pada orang dan masyarakat (WHO, 2001). Tingkat kebisingan dapat diukur, namun dampak dari kebisingan bersifat subjektif atau berbeda pada tiap individu (Mokhtar et al, 2007). Kebisingan yang sangat rendah, juga dapat menggagu orang yang aktivitasnya membutuhkan ketenangan misalkan orang yang sedang sakit, orang yang sedang beribadah dan orang yang sedang belajar (Djalatante,2010).

Sumber pokok dari polusi kebisingan adalah kebisingan kendaraan, diantaranya lalu lintas lintas jalan, lalu lintas rel dan lalu lintas bandar udara (Berglund et al,1999). Penyebab kebisingan kendaraan di jalan adalah mesin dan dari road contact kendaraan dan udara. Pada saat kecepatan lebih dari $60 \mathrm{~km} / \mathrm{jam}$, kebisingan road contact akan melebihi kebisingan mesin.

Polusi suara/kebisingan dapat di terjadi di mana saja, termasuk di Institusi pendidikan. Penelitian mengenai kebisingan di institusi pendidikan sudah mulai banyak dikaji, diantaranya karena dapat mengganggu proses belajar mengajar dan kinerja guru dan siswa (Debnath,et al., 2012). Baku mutu lingkungan kebisingan untuk kegiatan pendidikan adalah 55 dB (MENLH, 1996). Beberapa penelitian menunjukkan sekolah atau universitas yang berada di tepi jalan raya menunjukkan tingkat kebisingannya melampaui baku mutu. Penelitian dari Wafiroh (2013) di SMPN 2 Jember yang terletak ditepi jalan raya menunjukkan bahwa rata-rata kebisingan di tiga lokasi pengukuran melebihi baku mutu yaitu sebesar 66,61dB, 69,60 dB dan 55 dB.Kebisingan di SMP Negeri 6 Makasar yang melebihi baku mutu. Dari 7 titik lokasi pengukuran, semua lokasi menunjukkan diatas baku mutu. SMP Negeri 6 Makasar terletak di jalan arteri dengan volum kendaraan yang padat.

Aktivitas pada institusi pendidikan, seperti sekolah atau universitas idealnya berlokasi di lingkungan yang tenang, karena selama proses belajar mengajar diperlukan suasana yang hening dan tenang. Sehingga proses belajar mengajar dapat dilakukan sebaik mungkin dan diperoleh kemanfaatan kepada seluruh civitas akademik.

Penelitian ini mengambil studi kasus pada kawasan pendidikan di sepanjang jalur frontage road timur Jl.A.Yani Surabaya yang merupakan kawasan dengan beberapa aktivitas pendidikan dan sering terjadi kepadatan lalu lintas kendaraan bermotor dan jalur kereta api yang menjadi salah satu sumber kebisingan di kawasan tersebut. Terdapat 3 lokasi kawasan institusi pendidikan di sepanjang jalan ini yang akan menjadi titik penelitian yaitu: SDN Margorejo I/403, Kampus UIN Sunan Ampel Surabaya, dan SMKN 3 Surabaya. Adapun lokasi penelitian tersebut dapat dilihat pada Gambar 1 sampai 3.

Berdasarkan latar belakang masalah yang telah dijelaskan sebelumnya, maka perlu dilakukan penelitian mengenai tingkat kebisingan di kawasan tersebut. Diharapkan 
dari hasil penelitian ini dapat menjadi dasar dalam perencanaan lalu lintas atau perencanaan bangunan sehingga dapat meminimalkan permasalahan. Serta dapat menjadikan dasar untuk menghasilkan alternatif solusi dari permasalahan yang ada sesuai dengan karakteristik daerah tersebut.

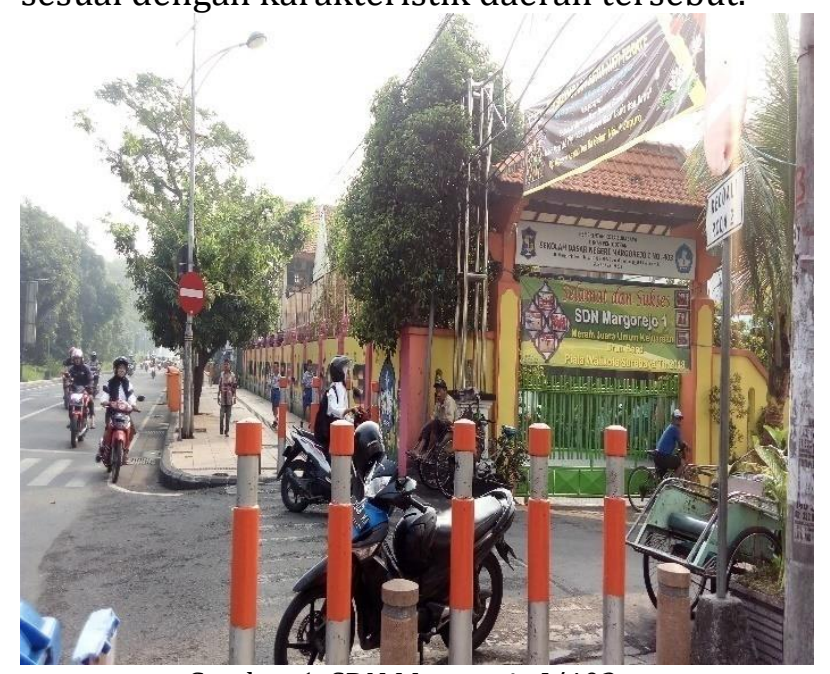

Gambar 1. SDN Margorejo I/403

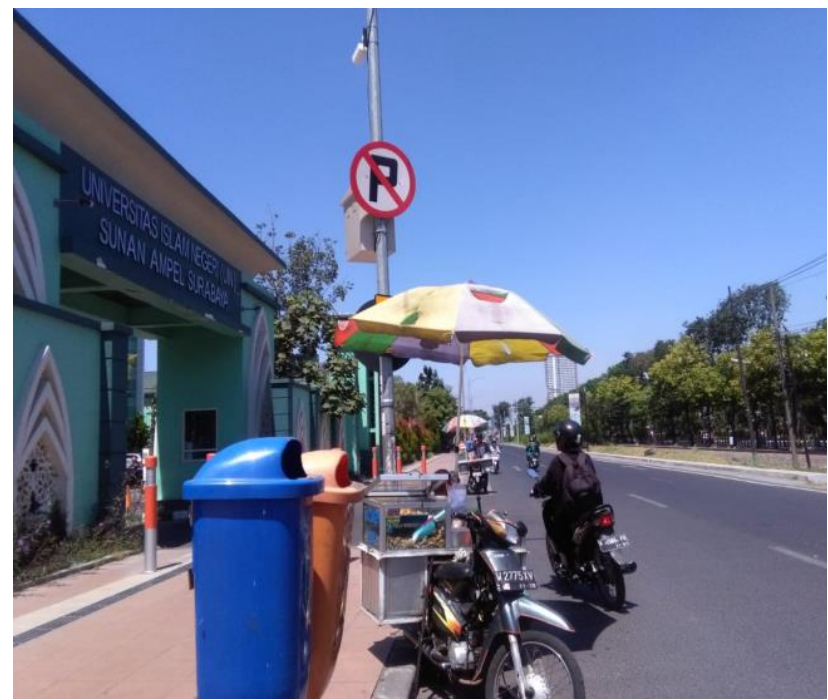

Gambar 2. Kampus UIN Sunan Ampel Surabaya

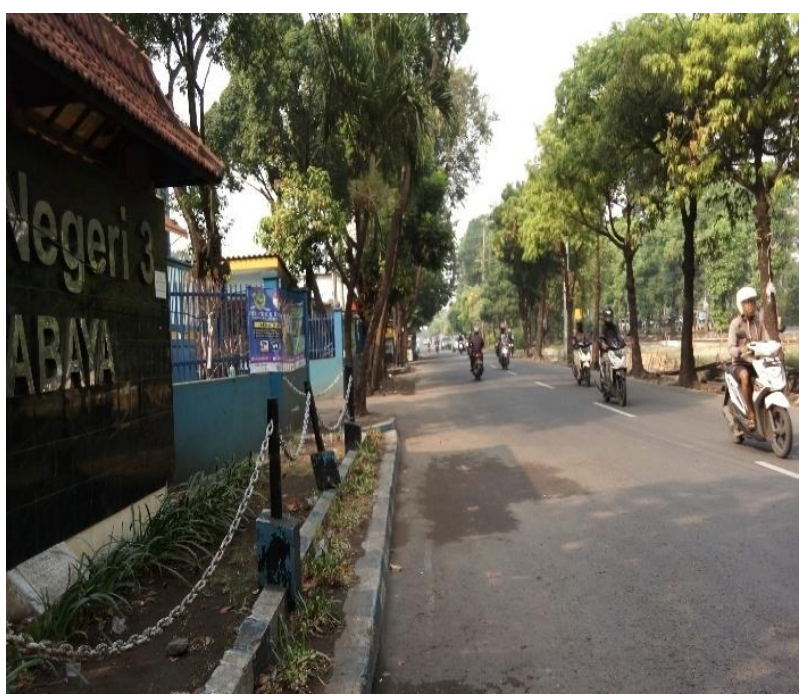

Gambar 3. SMKN 3 Surabaya

\section{METODE PENELITIAN}

\section{Metode}

Metode analisa yang digunakan dalam penelitian ini adalah penelitian analisis deskriptif yaitu metode yang memaparkan data keadaan yang sesungguhnya. Data primer didapatkan melalui pengukuran kebisingan dan observasi di lapangan. Sedangkan data sekunder yang berasaldari literatur-literatur pendukung digunakan untuk menyusun hasil penelitian.

\section{Lokasi penelitian}

Penelitian ini dilakukan di kawasan institusi pendidikan yang berada di sepanjang Frontage Road sisi Timur Jl.A.Yani Surabaya. Pengukuran kebisingan dilakukan di 3 lokasi di wilayah sepanjang jalan ini, yaitu:

1. Lokasi 1 di depan SDN Margorejo I/403

2. Lokasi 2 di depan UIN Sunan Ampel Surabaya

3. Lokasi 3 di depan SMKN 3 Surabaya

\section{Waktu penelitian}

Waktu pengukuran/sampling kebisingan dilakukan pada siang hari, dengan diwakili 4 waktu pengukuran yaitu:

1. L1 diambil pada jam 07.00 mewakili jam $06.00-09.00$

2. L2 diambil pada jam 10.00 mewakili jam $09.00-11.00$

3. L3 diambil pada jam 15.00 mewakili jam $14.00-17.00$

4. L4 diambil pada jam 20.00 mewakili jam $17.00-22.00$

Kegiatan pengukuran hanya dilakukan pada waktu siang hari karena aktivitas pendidikan pada institusi pendidikan di ketiga lokasi hanya dilakukan pada jam-jam tersebut.

\section{Alat dan Bahan}

Alat dan bahan yang digunakan pada penelitian ini meliputi:

1. Sound Level Meter

2. Stopwatch

3. Kamera

4. Alat Tulis

\section{Pengambilan data}

Pengambilan data dilakukan dengan mengacu pada KEPMENLH No 48 tahun 1996. Data diukur menggunakan sound level meter selama 10 menit untuk setiap pengukuran. Sedangkan untuk pembacaan dilakukan 
setiap 5 detik sehingga diperoleh sebanyak 120 data.

\section{Pengolahan data}

Data dihitung menggunakan persamaan berikut:

$$
\begin{aligned}
\mathrm{LS}= & 10 \log \\
& 1 / 16\left\{\mathrm{~T} 1 \cdot 10^{0,1 \mathrm{~L} 1}+\ldots \ldots . . .+\mathrm{T} 4 \cdot 10^{0,1 \mathrm{~L} 4}\right\} \mathrm{dB}
\end{aligned}
$$

Setelah diperoleh hasil besar kebisingan dalam satuan decibel (dB), kemudian dibandingkan dengan baku mutu tingkat kebisingan dengan mengacu pada KEPMENLH No 48 tahun 1996. Baku Mutu Tingkat Kebisingan sesuai baku mutu disajikan pada Tabel 1.

Tabel 1. Baku tingkat kebisingan

\begin{tabular}{clc}
\hline No & \multicolumn{1}{c}{$\begin{array}{c}\text { Peruntukan } \\
\text { Kegiatan }\end{array}$} & $\begin{array}{c}\text { Tingkat } \\
\text { Kebisingan } \\
\text { dB(A) }\end{array}$ \\
\hline 1 & Perumahan dan pemukiman & 55 \\
\hline 2 & Perdagangan dan jasa & 70 \\
\hline 3 & Perkantoran dan perdagangan & 65 \\
\hline 4 & Ruang terbuka hijau & 50 \\
\hline 5 & Industri & 70 \\
\hline 6 & $\begin{array}{l}\text { Pemerintah dan fasilitas } \\
\text { umum }\end{array}$ & 60 \\
\hline 7 & Rekreasi & 70 \\
\hline 8 & $\begin{array}{l}\text { Bandar Udara, Stasiun kereta } \\
\text { api, Pelabuhan laut }\end{array}$ & 70 \\
\hline 9 & Cagar budaya & 60 \\
\hline 10 & Rumah sakit dan sejenisnya & 55 \\
\hline 11 & Sekolah atau sejenisnya & 55 \\
\hline 12 & $\begin{array}{l}\text { Tempat ibadah atau } \\
\text { sejenisnya }\end{array}$ & 55 \\
\hline $\begin{array}{l}\text { (Sumber: Keputusan Menteri Lingkungan Hidup Kep- } \\
48 / \text { MENLH/1996, 25 November 1996) }\end{array}$ &
\end{tabular}

Dari hasil perbandingan, apabila melebihi baku mutu tingkat kebisingan yang telah ditetapkan, maka akan diberikan alternative solusi sesuai dengan karaketer daerah tersebut.

\section{HASIL DAN PEMBAHASAN}

Hasil dan pembahasan dari pengumpulan data primer berupa hasil pengukuran besaran nilai kebisingan dan observasi, serta didukung studi literatur yang berkaitan dengan penelitian ini.

\section{Kondisi Lokasi Penelitian}

Lokasi pengukuran kebisingan adalah institusi pendidikan di sepanjang frontageroad timur Surabaya. Ada 3 lokasi pengukuran yaitu di SDN Margorejo I/403, UIN Sunan Ampel Surabaya dan SMKN 3 Surabaya.

Frontage road timur Surabaya berada di sisi timur jalan Ahmad Yani yang merupakan jalan utama yang menghubungkan antara Surabaya dengan kota lainnya. Kepadatan di Jalan Ahmad Yani berdampak kepada Froantage road timur. Jika kondisi Jalan Ahmad Yani padat, maka frontage road menjadi alternatif jalan. Lalu lintas yang padat merupakan paparan bising di frontage road timur Surabaya, tapi kebisingan yang terjadi tidak hanya berasal dari kendaraan yang melaju di depannya. Sumber kebisingan lain juga berasal dari lalu lintas kereta api yang melaju di sisi kanan frontage road timur, dimana pada lokasi ini terdapat rel kereta api jurusan Surabaya-Banyuwangi dan SurabayaMalang.

\section{Analisis kebisingan di lokasi 1}

Lokasi 1 berada di depan SDN Margorejo I/403 Surabaya. Hasil pengukuran di lokasi ini disajikan pada Tabel 2. Hasil pengukuran menunjukkan bahwa kebisingan tertinggi terjadi pada waktu L4 dan terendah pada waktu L3. Nilai Ls kebisingan pada siang hari menunjukkan nilai yang telah melampaui baku mutu kebisingan di lingkungan pendidikan yaitu sebesar 82,2 dB. Nilai ini hampir sama besar dengan nilai kebisingan maksimum pada penilitian di sebuah institusi pendidikan di Nagaon Town, India, sebesar 80 dB(Debnath, et.al., 2012).

Tabel 2. Analisa Kebisingan SDN Margorejo I/403 Surabaya

\begin{tabular}{lc}
\hline Waktu & $\begin{array}{c}\text { Tingkat } \\
\text { kebisingan(dB) }\end{array}$ \\
\hline L1 & 80,17 \\
\hline L2 & 77,76 \\
\hline L3 & 76,42 \\
\hline L4 & 85,58 \\
\hline Ls & 82,2 \\
\hline Baku Mutu & 55 \\
\hline (Sumber: Hasil Perhitungan) & \\
\hline
\end{tabular}

\section{Analisis kebisingan di lokasi 2}

Pengukuran berikutnya dilakukan di lokasi 2 yang berada di depan kampus UIN Sunan Ampel Surabaya. Hasil pengukuran disajikan pada Tabel 3. Berdasarkan hasil pengukuran, didapatkan nilai kebisingan tertinggi tercatat pada saat L1 dan kebisingan terendah pada L2. Waktu saat L1 adalah pada saat jam sibuk, dimana mahasiswa mulai masuk kampus untuk melaksanakan kegiatan perkuliahan (proses belajar mengajar). 
Hasil perhitungan nilai kebisingan pada lokasi ini pada siang hari sebesar 79,76 dB. Besaran nilai ini telah melebihi baku mutu kebisingan di lingkungan institusi pendidikan.

Tabel 3. Analisa Kebisingan Kampus UIN Sunan Ampel Surabaya

\begin{tabular}{lc}
\multicolumn{1}{c}{ Waktu } & $\begin{array}{c}\text { Tingkat } \\
\text { kebisingan(dB) }\end{array}$ \\
\hline L1 (06.00-09.00) & 84,52 \\
\hline L2(09.00-14.00) & 74,55 \\
\hline L3(14.00-17.00) & 79,76 \\
\hline L4(17.00-22.00) & 79,99 \\
\hline & 79,76 \\
\hline Baku Mutu & 55 \\
\hline (Sumber: Hasil Perhitungan)
\end{tabular}

\section{Analisis Kebisingan di lokasi 3}

Lokasi 3 pada ini dilaksanakan di depan SMKN 3 Surabaya. Hasil pengukuran kebisingan disajikan pada Tabel 4. Dari hasil pengukuran, didapatkan nilai kebisingan tertinggi terdapat pada L3 yang mewakili jam 14.00-17.00 dengan waktu pengukuran dilakukan jam 16.00. Pada jam tersebut merupakan jam yang sibuk/padat, karena merupakan jam/waktu aktivitas pulang dari kantor. Untuk Ls di depan lokasi 3 melebihi baku mutu kebisingan lingkungan pendidikan yaitu sebesar 80,06 dB.

Tabel 4. Analisa KebisinganSMKN3 Surabaya

\begin{tabular}{lc}
\hline \multicolumn{1}{c}{ Waktu } & $\begin{array}{c}\text { Tingkat } \\
\text { kebisingan(dB) }\end{array}$ \\
\hline L1 (06.00-09.00) & 76,78 \\
\hline L2(09.00-14.00) & 77,08 \\
\hline L3(14.00-17.00) & 84,53 \\
\hline L4(17.00-22.00) & 80,04 \\
\hline Ls & 80,06 \\
\hline Baku Mutu & 55 \\
\hline (Sumber: Hasil Perhitungan)
\end{tabular}

\section{Analisis Kebisingan dari 3 lokasi}

Berdasarkan hasil pengukuran pada 3 lokasi penelitian, yaitu di depan SDN Margorejo I/403, depan UIN Sunan Ampel Surabaya, dan di depan SMKN 3 Surabaya, diperoleh nilai tingkat kebisingan dari ke-3 lokasi tersebut telah melampaui baku mutu KEPMENLH No.48 tahun 1996. Hal ini dikarenakan oleh aktivitas kendaraan bermotor yang cukup padat di kawasan ini. Aktivitas mobilisasi masyarakat Surabaya yang tinggi menyebabkan penggunaan kendaraan bermotor yang tinggi sehingga berdampak pada lingkungan sekitar, dalam hal ini adalah dampak kebisingan. Kendaran bermotor yang digunakan oleh murid/mahasiswa termasuk dalam sumber penyebab kebisingan (Debnath,et.al.,2012). Selain dari kendaraan bermotor, penyebab sumber kebisingan pada 3 lokasi penelitian tersebut adalah bersumber dari aktivitas kereta api. Aktifitas kereta api cukup berpengaruh mengingat jadwal kereta yang melintasi kawasan ini cukup sering. Jadwal kereta api yang melintasi kawasan ini dapat dilihat pada Tabel 5.

Tabel 5. Jadwal Kereta Api di Sekitar Frontage Road Surabaya

\begin{tabular}{|c|c|c|c|c|c|}
\hline \multicolumn{6}{|c|}{ Surabaya } \\
\hline $\begin{array}{l}\text { No. } \\
\text { KA }\end{array}$ & $\mathrm{KA}$ & Tujuan & Kelas & Tiba & $\begin{array}{l}\text { Berang } \\
\text { kat }\end{array}$ \\
\hline 174 & $\begin{array}{l}\text { Gaya Baru } \\
\text { Malam }\end{array}$ & $\begin{array}{l}\text { Surabaya } \\
\text { Gubeng } \\
\text { (SGU) }\end{array}$ & $\begin{array}{l}\text { Ekono } \\
\text { mi AC }\end{array}$ & 1.18 & 1.2 \\
\hline 295 & $\begin{array}{l}\text { Komuter } \\
\text { Surabaya- } \\
\text { Sidoarjo } \\
\text { (SuSi) }\end{array}$ & $\begin{array}{l}\text { Porong } \\
\text { (PR) }\end{array}$ & $\begin{array}{l}\text { Ekono } \\
\mathrm{mi}\end{array}$ & 4.15 & 4.22 \\
\hline 219 & Probowangi & $\begin{array}{l}\text { Banyuwa } \\
\text { ngi Baru } \\
(\mathrm{BW})\end{array}$ & & 4.31 & 4.35 \\
\hline $\begin{array}{l}449 / \\
442\end{array}$ & Rapih Dhoho & $\begin{array}{l}\text { Kerto } \\
\text { sono } \\
\text { (KTS) } \\
\text { bersambu } \\
\text { ng Blitar } \\
\text { (BL) }\end{array}$ & $\begin{array}{l}\text { Ekono } \\
\text { mi AC }\end{array}$ & 4.41 & 4.43 \\
\hline 459 & Penataran & $\begin{array}{l}\text { Blitar } \\
\text { (BL) via } \\
\text { Malang } \\
\text { Kotabaru } \\
\text { (ML) }\end{array}$ & & 4.5 & 4.52 \\
\hline 296 & $\begin{array}{l}\text { Komuter } \\
\text { Surabaya- } \\
\text { Sidoarjo } \\
\text { (SuSi) }\end{array}$ & & $\begin{array}{l}\text { Ekono } \\
\mathrm{mi}\end{array}$ & 6.45 & 6.47 \\
\hline 478 & $\begin{array}{l}\text { KRD } \\
\text { Kertosono }\end{array}$ & Kot & & 6.51 & 6.58 \\
\hline 460 & $\begin{array}{l}\text { Tumapel/Pe } \\
\text { nataran }\end{array}$ & & & 6.55 & 7.07 \\
\hline 471 & $\begin{array}{l}\text { KRD } \\
\text { Bojonegoro }\end{array}$ & $\begin{array}{l}\text { Sidoarjo } \\
\text { (SDA) }\end{array}$ & $\begin{array}{l}\text { Ekono } \\
\text { mi AC }\end{array}$ & 7.16 & 7.18 \\
\hline 461 & Penataran & $\begin{array}{l}\text { Blitar } \\
\text { (BL) via } \\
\text { Malang } \\
\text { Kotabaru } \\
\text { (ML) }\end{array}$ & & 7.46 & 7.48 \\
\hline 252 & $\begin{array}{l}\text { Arjuna } \\
\text { Ekspres }\end{array}$ & $\begin{array}{l}\text { Surabaya } \\
\text { Kota (SB) }\end{array}$ & $\begin{array}{l}\text { Ekono } \\
\text { mi }\end{array}$ & 7.52 & 7.54 \\
\hline
\end{tabular}




\begin{tabular}{|c|c|c|c|c|c|}
\hline $\begin{array}{l}\text { No. } \\
\text { KA }\end{array}$ & $\mathrm{KA}$ & Tujuan & Kelas & Tiba & $\begin{array}{l}\text { Berang } \\
\text { kat }\end{array}$ \\
\hline 179 & Pasundan & $\begin{array}{l}\text { Bandung } \\
\text { Kiaracond } \\
\text { ong (KAC) }\end{array}$ & & 8.19 & 8.21 \\
\hline $\begin{array}{l}451 / \\
444\end{array}$ & Rapih Dhoho & $\begin{array}{l}\text { Kertosono } \\
\text { (KTS) } \\
\text { bersambu } \\
\text { ng Blitar } \\
\text { (BL) }\end{array}$ & & 8.31 & 8.33 \\
\hline $\begin{array}{l}190 / \\
187\end{array}$ & Logawa & $\begin{array}{l}\text { Purwoker } \\
\text { to (PWT) }\end{array}$ & & 9.19 & 9.21 \\
\hline 462 & Penataran & $\begin{array}{l}\text { Surabaya } \\
\text { Kota (SB) }\end{array}$ & & 9.32 & 9.34 \\
\hline $\begin{array}{l}472 / \\
473\end{array}$ & $\begin{array}{l}\text { KRD } \\
\text { Bojonegoro }\end{array}$ & $\begin{array}{l}\text { Surabaya } \\
\text { Pasarturi } \\
\text { (SBI) } \\
\text { bersambu } \\
\text { ng } \\
\text { Bojonegor } \\
\text { o (BJ) }\end{array}$ & $\begin{array}{l}\text { Ekono } \\
\text { mi AC }\end{array}$ & 9.56 & 9.58 \\
\hline $\begin{array}{l}441 / \\
450\end{array}$ & Rapih Dhoho & $\begin{array}{l}\text { Surabaya } \\
\text { Kota (SB) }\end{array}$ & & 10.33 & 10.35 \\
\hline 477 & $\begin{array}{l}\text { KRD } \\
\text { Kertosono }\end{array}$ & $\begin{array}{l}\text { Kertosono } \\
\text { (KTS) }\end{array}$ & & 10.46 & 10.48 \\
\hline 463 & Penataran & $\begin{array}{l}\text { Blitar } \\
\text { (BL) via } \\
\text { Malang } \\
\text { Kotabaru } \\
\text { (ML) }\end{array}$ & & 11.41 & 11.43 \\
\hline 173 & $\begin{array}{l}\text { Gaya Baru } \\
\text { Malam }\end{array}$ & $\begin{array}{l}\text { Jakarta } \\
\text { Pasar } \\
\text { Senen } \\
\text { (PSE) }\end{array}$ & & 12.04 & 12.06 \\
\hline $\begin{array}{l}453 / \\
446\end{array}$ & Rapih Dhoho & $\begin{array}{l}\text { Kertosono } \\
\text { (KTS) } \\
\text { bersambu } \\
\text { ng Blitar } \\
\text { (BL) }\end{array}$ & & 12.16 & 12.18 \\
\hline 297 & $\begin{array}{l}\text { Komuter } \\
\text { Surabaya- } \\
\text { Sidoarjo } \\
\text { (SuSi) }\end{array}$ & $\begin{array}{l}\text { Porong } \\
\text { (PR) }\end{array}$ & $\begin{array}{l}\text { Ekono } \\
\mathrm{mi}\end{array}$ & 13.31 & 13.37 \\
\hline $\begin{array}{l}196 / \\
193\end{array}$ & Sri Tanjung & $\begin{array}{l}\text { Yogyakart } \\
\text { a } \\
\text { Lempuyan } \\
\text { gan (LPN) }\end{array}$ & & 13.39 & 13.41 \\
\hline $\begin{array}{l}194 / \\
195\end{array}$ & & $\begin{array}{l}\text { Banyuwa } \\
\text { ngi Baru } \\
(\mathrm{BW})\end{array}$ & & 14.34 & 14.36 \\
\hline $\begin{array}{l}188 / \\
189\end{array}$ & Logawa & $\begin{array}{l}\text { Surabaya } \\
\text { Gubeng } \\
\text { (SGU) } \\
\text { bersambu } \\
\text { ng Jember } \\
\text { (JR) }\end{array}$ & $\begin{array}{l}\text { Ekono } \\
\text { mi AC }\end{array}$ & 14.45 & 14.47 \\
\hline 464 & Penataran & & & 14.52 & 14.55 \\
\hline $\begin{array}{l}443 / \\
452\end{array}$ & Rapih Dhoho & Kota (SB) & & 15.27 & 15.32 \\
\hline
\end{tabular}

\begin{tabular}{|c|c|c|c|c|c|}
\hline $\begin{array}{l}\text { No. } \\
\text { KA }\end{array}$ & KA & Tujuan & Kelas & Tiba & $\begin{array}{l}\text { Berang } \\
\text { kat }\end{array}$ \\
\hline $\begin{array}{l}474 / \\
475\end{array}$ & $\begin{array}{l}\text { KRD } \\
\text { Bojonegoro }\end{array}$ & $\begin{array}{l}\text { Sidoarjo } \\
\text { (SDA) }\end{array}$ & & 16.14 & 16.16 \\
\hline 480 & $\begin{array}{l}\text { KRD } \\
\text { Kertosono }\end{array}$ & & & 16.2 & 16.22 \\
\hline 298 & $\begin{array}{l}\text { Komuter } \\
\text { Surabaya- } \\
\text { Sidoarjo } \\
\text { (SuSi) }\end{array}$ & $\begin{array}{l}\text { Surabaya } \\
\text { Kota (SB) }\end{array}$ & $\begin{array}{l}\text { Ekono } \\
\mathrm{mi}\end{array}$ & 16.55 & 16.57 \\
\hline $\begin{array}{l}455 / \\
448\end{array}$ & Rapih Dhoho & $\begin{array}{l}\text { Kertosono } \\
\text { (KTS) } \\
\text { bersambu } \\
\text { ng Blitar } \\
\text { (BL) }\end{array}$ & & 17.46 & 17.48 \\
\hline 476 & $\begin{array}{l}\text { KRD } \\
\text { Bojonegoro }\end{array}$ & $\begin{array}{l}\text { Surabaya } \\
\text { Pasarturi } \\
\text { (SBI) }\end{array}$ & $\begin{array}{l}\text { Ekono } \\
\text { mi AC }\end{array}$ & 17.52 & 17.55 \\
\hline 465 & Penataran & $\begin{array}{l}\text { Blitar } \\
\text { (BL) via } \\
\text { Malang } \\
\text { Kotabaru } \\
\text { (ML) }\end{array}$ & & 17.56 & 17.58 \\
\hline 299 & $\begin{array}{l}\text { Komuter } \\
\text { Surabaya- } \\
\text { Sidoarjo } \\
\text { (SuSi) }\end{array}$ & $\begin{array}{l}\text { Porong } \\
\text { (PR) }\end{array}$ & $\begin{array}{l}\text { Ekono } \\
\text { mi }\end{array}$ & 18.07 & 18.09 \\
\hline $\begin{array}{l}445 / \\
454\end{array}$ & Rapih Dhoho & $\begin{array}{l}\text { Surabaya } \\
\text { Kota (SB) }\end{array}$ & $\begin{array}{l}\text { Ekono } \\
\text { mi AC }\end{array}$ & 18.13 & 18.15 \\
\hline 251 & $\begin{array}{l}\text { Arjuna } \\
\text { Ekspres }\end{array}$ & $\begin{array}{l}\text { Madiun } \\
(\mathrm{MN})\end{array}$ & $\begin{array}{l}\text { Ekono } \\
\mathrm{mi}\end{array}$ & 18.16 & 18.18 \\
\hline 466 & Penataran & $\begin{array}{l}\text { Surabaya } \\
\text { Gubeng } \\
(\mathrm{SGU})\end{array}$ & & 19.24 & 19.27 \\
\hline 479 & $\begin{array}{l}\text { KRD } \\
\text { Kertosono }\end{array}$ & $\begin{array}{l}\text { Kertosono } \\
\text { (KTS) }\end{array}$ & $\begin{array}{l}\text { Ekono } \\
\text { mi AC }\end{array}$ & 19.26 & 19.28 \\
\hline 467 & $\begin{array}{l}\text { Tumapel/Pe } \\
\text { nataran }\end{array}$ & $\begin{array}{l}\text { Malang } \\
\text { Kotabaru } \\
(\mathrm{ML})\end{array}$ & & 20.07 & 20.09 \\
\hline 300 & $\begin{array}{l}\text { Komuter } \\
\text { Surabaya- } \\
\text { Sidoarjo } \\
\text { (SuSi) }\end{array}$ & $\begin{array}{l}\text { Surabaya } \\
\text { Kota (SB) }\end{array}$ & $\begin{array}{l}\text { Ekono } \\
\mathrm{mi}\end{array}$ & 20.29 & 20.31 \\
\hline 220 & Probowangi & & & 20.43 & 20.45 \\
\hline 180 & Pasundan & $\begin{array}{l}\text { Surabaya } \\
\text { Gubeng } \\
(\mathrm{SGU})\end{array}$ & $\begin{array}{l}\text { Ekono } \\
\mathrm{mi} \mathrm{AC}\end{array}$ & 21.29 & 21.31 \\
\hline 468 & Penataran & & & 22.2 & 22.22 \\
\hline $\begin{array}{l}447 / \\
456\end{array}$ & Rapih Dhoho & $\begin{array}{l}\text { Surabaya } \\
\text { Kota (SB) }\end{array}$ & & 22.41 & 22.43 \\
\hline
\end{tabular}

Berdasarkan hasil analisis, nilai kebisingan dari ketiga lokasi sampling disajikan pada Tabel 6. Sedangkan grafik analisa kebisingan dari ketiga lokasi sampling/penelitian disajikan pada Gambar 4.

Tabel 6. Hasil Analisa Kebisingan 3 Lokasi Penelitian 


\begin{tabular}{lc}
\hline \multicolumn{1}{c}{ Lokasi } & $\begin{array}{c}\text { Tingkat } \\
\text { kebisingan(dB) }\end{array}$ \\
\hline SDN Margorejo I/403 & 82,2 \\
\hline UIN Sunan Ampel & 79,76 \\
\hline SMKN 3 Surabaya & 80,06 \\
\hline Baku Mutu & 55 \\
\hline
\end{tabular}

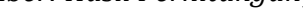

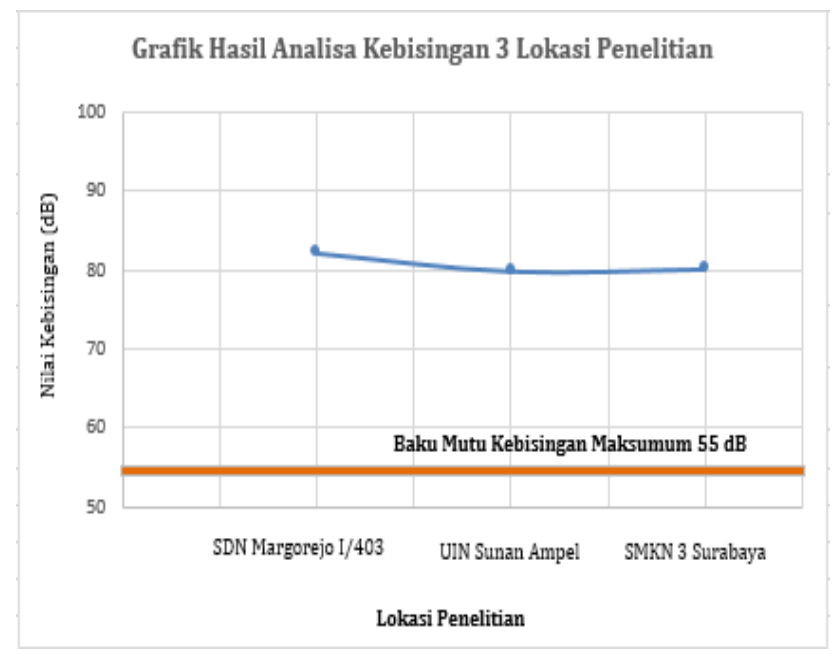

Gambar 4. Grafik Hasil Analisa Kebisingan 3 Lokasi Penelitian

\section{Alternatif Solusi}

Alternatif solusi diberikan berdasarkan kondisi wilayah perencanaan yang juga dapat dilihat pada Gambar 1-3. Kawasan sepanjang frontage road sisi Timur jalan A.Yani Surabaya sebagian besar berupa perkerasan atau paving Bahan tersebut berupa perkerasan/paving mengakibatkan bunyi/suara mempunyai sifat memantulkan bunyi/suara sehingga diperlukan bahan yang dapat menyerap suara/bunyi sehingga dapat mengurangi kebisingan.

Selain hal tersebut, jarak dari sumber kebisingan juga relative dekat. Pengurangan kebisingan dapat dilakukan dengan pelarangan pemakaian mobil atau motor dengan knalpot terbuka, perbaikan kualitas sarana transportasi umum sehingga pemilihan transportasi umum akan menjadi pilihan utama dalam melakukan aktifitas sehari-hari.

Adapun penanganan yang dilakukan dengan melihat kondisi lingkungan disekitar lokasi penelitian, yaitu: berupa penanaman tanaman-tanaman kecil (sound barrier) dan pohon-pohon besar/tingkat tiang di pinggir jalan sepanjang frontage road sisi Timur Jalan A.Yani Surabaya. Penanaman tanaman rambat/tanaman hias pada dinding bangunan di institusi pendidikan juga dapat mengurangi kebisingan. Hal ini dilakukan karena sound barrier dengan jumlah dan luasan pepohonan di satu baris penanaman, dapat mengurangi kebisingan hingga 8dB setiap $\mathrm{m}^{2}$ pada area di bawah ketinggian pohon (Chistiaji, 2009).

\section{KESIMPULAN}

Berdasarkan hasil pengukuran pada 3 lokasi penelitian, diperoleh nilai tingkat kebisingan pada masing-masing lokasi penelitian. Besar nilai kebisingan padaSDN Margorejo I/403 sebesar 82,2 dB, Kampus UIN Sunan Ampel Surabaya sebesar 79,76 dB, dan SMKN 3 Surabaya sebesar 80,06 dB. Nilai tingkat kebisingan tersebut telah melampaui baku mutu yang di tetapkan sesuai KepMenLH No 48 tahun 1996 yaitu maksimal 55 dB untuk kawasan pendidikan. Sumber kebisingan tersebut berasal dari aktivitas kendaraan bermotor yang cukup padat. Selain karena aktivitas kendaraan bermotor, penyebab sumber kebisingan pada 3 lokasi penelitian tersebut adalah bersumber dari aktivitas kereta api yang berada di sekitar frontage road Surabaya. Serta jarak sumber kebisingan yang relatif dekat juga menyebabkan nilai kebisingan yang tinggi.

Pengurangan kebisingan dapat dilakukan dengan pelarangan pemakaian mobil atau motor dengan knalpot terbuka, perbaikan kualitas sarana transportasi umum sehingga pemilihan transportasi umum akan menjadi pilihan utama dalam melakukan aktifitas sehari-hari. Selain itu, berdasarkan kondisi di daerah tersebutdimana jarak sumber kebisingan yang relative dekat dan kondisi lingkungan yang sebagian besar berupa perkerasan/paving yang bersifat memantulkan suara/bunyi, diperlukan bahan yang dapat menyerap suara/bunyi sebagai solusi untuk mengurangi kebisingan, yaitu berupa penanaman tanaman-tanaman kecil diantara pohon-pohon besar di pinggir jalan, danpenanaman tanaman rambat/tanaman hias pada dinding juga bisa mengurangi kebisingan.

\section{DAFTAR PUSTAKA}

Anonim. 1996.Baku Tingkat Kebisingan Menteri Negara Lingkungan Hidup. Nomor : Kep48/MENLH/II/1996/25/Nopember 1996. Jakarta. 
Anonim. 1997.Grafik Perjalanan Kereta Api (GAPEKA) tahun 2017. Direktorat Jenderal Perkeretaapian (Ditjen KA) Kementerian Perhubungan RI

Berglund, B., Lindvall, T., dan Schwela, D. H. 1999. Guidelines For Community Noise. World Health Organization (WHO), Geneva. London, UK.

Debnath, D. , Nath, S.K dan Barthakur, N.K. 2012. Environmental Noise Pollution in Educational Institutes of Nagaon Town, Assam,India. Global Journal ofScience Frontie Research Environmental \&Earth Sciences. Vol 12Issue 1 Version 1.0 Tahun 2012

Djalante, S. 2010. Analisis Tingkat Kebisingan Di Jalan Raya Yang Menggunakan Alat Pemberi Isyarat Lalu Lintas (APIL) (Studi Kasus: Simpang Ade Swalayan). Jurnal SMARTek. Vol. 8 No. 4. November 2010: 280-300.

Keputusan Menteri Lingkungan Hidup, No. 48/MENLH/11/1996 tentang Baku Tingkat Kebisingan.

Mokhtar.M, Kamaruddin.S, Khan.ZA, Mallick Z.2007. Study On Effect Of Noise On Industrial Worker In Malaya. Jurnal Teknologi Universiti Teknologi Malaysia. 46(A) Jun:2007:p 17-30

Ramli,M.I,Rauf.S,Achmad Fiqri A.M.2015. Studi Tingkat Kebisingan Pada SMP Negeri 6 Di Kota Makassar. http://repository.unhas.ac.id/bits tream/handle/123456789/18867 /jurnal.pdf?sequence $=1$ (sitasi tanggal 5 Februari 2018)

Wafiroh .A.H. 2013. Pengukuran Tingkat Kebisingan Di Lingkungan Smpn 2 Jember.Skripsi.

Fakultas Matematika Dan Ilmu Pengetahuan Alam. Jurusan Fisika. Universitas Jember.

WHO Information Fact Sheets. 2001. Occupational And Community Noise. WHO OMS. http//www.who.int/inf- fs/en/fact258.html (diakses tanggal 07 September 2012). 